\title{
Exploring the Poetic Capital in Out-of-School L2 Poetry Writing Practices
}

\author{
ZHANG Meng \\ The Ohio State University, Ohio, USA
}

\begin{abstract}
In order to humanize the teaching, learning, and researching of second language (L2) writing, a growing number of L2 writing researchers and practitioners incorporate creative (e.g., poetry and novels) and expressive genres (e.g., reading response and reflective journals) into the design and implementation of their L2 writing courses given the specific affordances of these genres in facilitating L2 learners' social and cognitive growths. Nevertheless, such humanized and meaningful literacy practice, in the form of L2 creative writing, has been rarely investigated in out-of-school contexts, where writers autonomously elicit their sociocultural and emotional resources and capitals in free and self-regulated writing processes. This study addresses such gap by examining the salient characteristics of out-of-school L2 poetry writing workshop practice as well as potential connections between such practice and in-school, formal disciplinary studies. Data were collected through workshop observations, semi-structured interviews, and written texts. Findings indicated that the L2 writers' cross-cultural experiences and transferrable interdisciplinary thoughts were two essential components of their poetic capitals in transforming them to be intellectual and creative L2 writers.
\end{abstract}

Keywords: humanized and meaningful literacy practice, L2 poetry writing, poetic capital, cross-cultural experience, interdisciplinarity, creativity

\section{Introduction}

Learning to write in a second language (L2) involves more than intellectual abilities: It activates the learner as "living, thinking, experiencing, and feeling person" (Hanauer, 2012, p. 105) who draws upon a wide range of sociocultural, educational, and emotional resources to make meaning of the entire writing process. In 2012, Hanauer promoted the concept of "meaningful literacy instruction" (Hanauer, 2012, p. 108) by incorporating poetry reading and writing practices into his English as a Second Language (ESL) writing classroom norms, which provided L2 writers with spaces of voicing their emotions, presenting their expertise of cross-cultural experiences, and evolving their writer identity and ownership of a second language in creative manners.

Align with Hanauer's (2012) notion of “meaningful literacy instruction" (p. 108), which positioned students' personal experience, history, and sociocultural contextualization at the heart of the teaching and learning of L2 writing, several researchers, such as Dai (2015), Iida (2010), Saito (2008), and Stewart (2010), re-designed their L2 writing classrooms by introducing creative (e.g., poetry) and expressive (e.g., personal narratives and

ZHANG Meng, Ph.D. candidate, Foreign and Second Language Education, Department of Teaching and Learning, College of Education and Human Ecology, The Ohio State University. 
reader responses) genres to students and walking them through the stages of reading, writing, and sharing creative and expressive texts. These researchers found through observing students' classroom behaviors, interviewing them regarding their attitudes toward creative/expressive literacy practices, and analyzing their written drafts that the students gradually grew as more enjoyable, confident, and self-regulated L2 writers through interacting and collaborating with peers, sharing voice, and demonstrating their expertise of producing creative/expressive texts based upon reflecting and exploring their personal cross-cultural encounters, unique oversea studying experiences, and rich emotional attachments.

However, L2 learners' meaningful literacy practice has rarely been investigated in out-of-school contexts. Little is known about the characteristics, resources, benefits, and challenges that $\mathrm{L} 2$ learners have for practicing creative/expressive writings in the informal, loosely-structured, and non-schooling environments. Therefore, this study aims at bridging this gap through exploring the features of out-of-school creative literacy practice and seeking for potential connections between such practice and L2 writers' in-school disciplinary studies.

Based on the above preliminary inquiries, this study was conducted within Flow Wind L2 Poetry Workshop through adopting an ethnographic method. Flow Wind could be defined as an out-of-school meaningful literacy space for L2 poetry writers to interact with one another in the processes of composing, exchanging, and performing their creative voices. Data was collected from November 2015 to March 2016, including five fully audio-recorded workshop meetings, field notes, audio-recorded, semi-structured individual interviews, digital records of online textual interaction, and participants' written drafts. I searched for patterns and themes and the linkages among them through open and axial coding procedures and discovered salient characteristics of the L2 writers, their poetry writings, and the writer group dynamics. Findings indicated that it would be important to encourage L2 writers to have out-of-school literacy practice, which could be perceived as an opportunity to relieve academic pressure, exchange cross-cultural experience and individual voice, build up "literary friendships" (Craig \& Dubois, 2010, p. 453), offer one another emotional and social supports in everyday life, and practice and improve creative, critical, and interdisciplinary thoughts.

\section{Literature Review}

\section{L2 Meaningful Literacy Practice}

An increasing number of L2 writing researchers start to problematize the decontextualized language classrooms which intensively direct learners' attention to language form and grammatical accuracy. They (e.g., Dai, 2015; Iida, 2008, 2010; Leal, 2015; Lee, 2013; Myskow \& Gordon, 2010; Ostrow \& Chang, 2012; Saito, 2008; Stewart, 2010) have observed that the product-based, grammar-translation teaching method makes a large group of L2 learners lack of confidence while being afraid of making mistakes in their writing practices (Iida, 2008). The teaching and learning that solely focus on linguistic, structural, and cognitive terms ignore learners' emotions, sociocultural experiences, local resources, and personal insights that collaboratively contribute to the entire process of learning a second language. Therefore, scholars, such as Hanauer (2012), Kramsch (2006), and Newman and Hanauer (2005), criticize the grammar-translation approach adopted in conventional L2 writing classrooms and promote to humanize L2 writing practices by positioning learners' needs and expectations as the heart of all literacy practices.

The research endeavor of creating humanizing spaces for L2 practice has been presented in Hanauer's (2012) concept of "meaningful literacy instruction" (p. 108). It addresses the design of holistic activities in L2 classrooms, integrating learners' affect, intention, personal history, and indication for future actions into the 
community of creative literacy practice; it also emphasizes the teacher-researcher's participation in learner community to advance their understanding towards each individual as living, feeling, and thinking person (Hanauer, 2012) while cultivating their expertise of voicing personal experience and emotion in creative and artistic ways.

Dai's (2015) research on EFL English major college students' creative writing modeled the application of the framework of meaningful literacy instruction in real L2 classroom settings by introducing his students to a diverse and dynamic world of L2 literature. In reading selection and writing task design, Dai (2015) triangulated resources from required course readings, related documentary movies, and other students' written texts to emphasize the importance for participants to learn English from multimodal literacies, present their authentic and critical responses, share them with peers, and learn the meaning of life from others' stories and narratives. As the teacher-researcher, Dai (2015) also shared his L2 creative writing in progress to let students make comments and suggestions, which largely advanced his relationship with students and further encouraged students to experience different stages of composing a creative text.

In Dai's (2015) meaningful literacy instruction, he spared no efforts in linking students' sociocultural experiences with the content of reading and writing materials, encouraging them to voice their emergent feelings and emotions in multiple creative ways. Iida's $(2008,2010)$ studies on EFL college students' haiku poetry writing presented similar ideas on humanizing L2 writing practice by encouraging students to find a moment of speaking themselves to the nature, reflecting the meaning of that moment and framing it within poetic structures by using condensed yet imaginative languages. Students in Iida's L2 haiku poetry class were reported to value the opportunities of linking their English language learning with the appreciation of nature and life.

What is the research gap? However, through reviewing literature, I find that L2 meaningful literacy has been mostly investigated within classroom settings, in which students read and write creative texts under the teacher-researchers' guidance (e.g., Dai, 2015; Iida, 2010; Saito, 2008). Little is known about such practice in out-of-school contexts, where L2 learning is perceived as a more autonomous and self-regulated process. Thus, this study is built upon current literature, extending the investigation on L2 creative writing practices to out-of-school L2 learner community to advance practitioners' understandings toward the characteristics, challenges, and resources learners have in such L2 practices.

\section{Poetry as a Key Genre in L2 Meaningful Literacy Practices}

In realizing L2 meaningful literacy practices, poetry has been frequently introduced to L2 classrooms as an innovative pedagogical intervention that "moves teachers and learners out of the repression, violence and passivity that characterized apartheid education into free and peaceful space that facilitate agency, a tolerance of differences, and the development of creativity" (Newfield \& D'adbon, 2015, p. 515). Poetry are believed to provide both L2 teachers and learners with new cognitive and emotional insights through "linguistic negotiation" (Hanauer, 2010, p. 15): On one hand, it presents L2 writers' experiences, thoughts, emotions, and feelings via a self-referential use of L2 language (Hanauer, 2010); on the other hand, it advances audience's understandings towards specific poetic expressions through listening to and discussing on the writers' voices. As Hanauer (2012) mentions according to his studies on the corpus of L2 learners' poetic texts, he has always been surprised by the way each individual uniquely understands their own lived experience and therefore perceiving writers' reservoir of memories as resources for producing significant meaningful content. 
In a number of cases, L2 poetry practice has been investigated in classrooms of immigrants and bilingual students (e.g., Cahnmann, 2006; Saito, 2008; Stewart, 2010). Researchers as or with classroom teachers contextualize poetry reading and writing tasks to their students' immigrant, bilingual, or bicultural experiences, freeing their thoughts, and even encouraging the use of their first languages to foster their discovery of selves and the meaning of life.

For instance, Saito (2008) and Stewart (2010) taught their immigrant students to read and write English poetry and constantly made them share thoughts and written drafts with peers. They found through such interactive practice that the gap between their students' L2 speaking and writing had been bridged to some extent; students also reported that they enjoyed L2 poetry practice since it connected L2 literacy with their personal experiences, making them write and share their voices with little constraints on forms or grammatical accuracy. From the researchers' perspective, Saito (2008) and Stewart (2010) found themselves having new understandings towards students' cultures and beliefs through diving into their meaningful literacy practice communities, learning about their interactive languages and cultural references. After finishing classes, Saito (2008) and Stewart (2010) also compelled their students' poetry into anthologies to pass their creative voices to faculty and new students, which largely enhanced immigrant L2 learners' writer identity, improving their confidence in future meaningful literacy practices.

What is the research gap? Therefore, based on the existing literature, this study adopts poetry as the key creative genre in out-of-school L2 practice to explore the resources participants elicit to support their meaningful literacy composition and discussion, investigating the multimodal and interdisciplinary features of such resources that make L2 learners socioculturally contextualized individuals.

\section{Research Questions}

Based on the review of literature and statement of research gaps on L2 meaningful literacy practice in form of poetry writing and sharing, this study explores the following questions contextualized within the Flow Wind Out-of-School L2 Poetry Workshop:

(1) What are the characteristics of Flow Wind out-of-school L2 poetry practice?

(2) What are the Flow Wind L2 poetry writers' perceptions toward the relationship between their out-of-school creative literacy practice and in-school disciplinary studies?

\section{Theoretical Framework of Capitals}

In order to explore the characteristics, resources, connections, and implications of L2 out-of-school meaningful literacy practice, this study is framed within the theory of cultural and social capitals promoted by Bourdieu (1986), emphasizing L2 learners' personal history, experience, education, memory, emotion, and reflection as resources that accumulatively influence their creative literacy practices in various ways.

According to Bourdieu (1986), cultural capital has three states of representation, namely, the embodied state which indicates a long-lasting labor of inculcation and assimilation that allows a person to work on self-improvement and integration to certain habitus; the objectified state is presented in form of cultural goods, such as books, instruments, paintings that can be transmitted instantaneously; and the institutionalized state which specifically suggests the educational qualification that cultivates a person's intellectual and academic growths. 
The theory of cultural capital will inform the development of humanized L2 meaningful literacy practice in significant ways because it directs practitioners' attention to the three crucial states closely associated with L2 learners' first language (L1) ideology and cross-cultural thinking patterns that largely affect their L2 learning processes.

Besides cultural capital, social capital (Bourdieu, 1986) indicates L2 learners' social belongings exhibit during their literacy practices, namely, the degree of intimacy that learners find between their personal experiences and the artifices being presented.

By obtaining knowledge on L2 learners' cultural capital and social capital that function actively in the process of their L2 literacy practice and social identity construction, teachers and researchers are expected to have better understandings towards the complex, dynamic, and dialogic feature of L2 learning in out-of-school contexts.

In this study, L2 learners' cultural and social capitals can be synthesized to the notion of Poetic Capital, specifically suggesting learners' long-lasting, ongoing accumulation of cultural, social, educational, literary, experiential, and emotional resources at different stages of their lives that collectively function in the processes of their out-of-school, self-regulated L2 poetry reading and writing practices.

\section{The Study}

\section{Context}

Historical backgrounds and connections. This study has been conducted within my self-organized L2 poetry workshop, named Flow Wind, which partially represented the practice of Poetry Slam emerged in 1980s in Chicago, US (Gregory, 2008). As a new and growing artistic movement, Poetry Slam in modern dominant literature world is considered as "a genre, a game, a community, an educational device, a career path and a gimmick" (Gregory, 2008, p. 66). In Flow Wind, we refashion the key procedures in Poetry Slam practice by adding poetry discussion sessions after group poetry reading, aiming at creating more socially interactive spaces for writers to talk about the stories and experiences behind their written texts, sharing their creativity and originality from page to stage (Elting \& Firkins, 2006). Another major difference between Flow Wind poetry practice and Poetry Slam is that the former does not hold for poetry competition purposes as the latter does.

The establishment of Flow Wind L2 Poetry Workshop. Flow Wind was established in May 2015 in Columbus, Ohio, through local Chinese Student and Scholar Society (CSSS) online enrollment. The workshop consists of five Chinese undergraduate and graduate students in the city of Columbus who share the interest of reading and writing poetry in English as second language. I am the main operator of the workshop, being responsible for organizing workshop meetings. After getting the IRB approval for taking the entire workshop to study in November 2015 and obtaining the other four workshop members' signed Informed Consent Forms subsequently, I take the role of researcher and participant observer in addition to the role of workshop organizer.

Workshop procedures. Since establishment, Flow Wind runs monthly meetings in our favorite local Gibson Coffee Shop (pseudo name). During the first meeting, we collaboratively set up rules for participation and they are also applied to the research-purpose workshop meetings held between November 2015 and March 2016. By attending each meeting, each participant is invited to bring one original poem written in English with enough hardcopies for others to refer to; there are no specific assigned themes to write and participants are free to choose writing styles (e.g., template poems or free verses). Each meeting holds up to three hours, during 
which participants take turns sharing poems via reading-aloud or performing within the group. After each reading, we have a 15-minute group discussion on the poem regarding the writer's motivation to write, written techniques, writing experiences and reflections, offering suggestions for improvements or revisions.

\section{Participants}

All members in Flow Wind are advanced L2 learners who agree to participate in the current study and exhibit the willingness of talking about their L2 poetry writings associated with relative educational experiences, subtle emotional attachments, and multi-facet self-reflections in-depth.

Steve (pseudo name) transferred high school from China to US and during the period of workshop participation, he was a junior undergraduate student majored in chemical engineering and his excellent academic performance granted him with a one-year teaching associate part-time job on campus. Steve was proficient in Chinese and English and he had experience of reading and writing English lyric poetry. He quite enjoyed singing his original lyric poems with playing guitar but addressed that he had no formal educational experience of studying English poetry in college.

Ziyong (pseudo name) was in his first-year bioscience doctoral study upon attending poetry workshop activities. It was the first time for Ziyong to live and study in US and he kept the habit of writing Chinese and English template poems to express his feelings towards being far from hometown, encountering unfamiliar Western cultures, and experiencing academic competitions in everyday life.

Piaet (pseudo name) was a second-year doctoral student in physics study. He enjoyed natural scenes and social atmosphere in Columbus and wrote free verses and template poems in English upon discoveries of the beauty of nature and newly established friendships.

William (pseudo name) was a second-year exchange doctoral student from one top-tier scientific research institution in China. Majoring in biochemistry, William spent most time in lab with complicated projects at hand and seldom hanged out with friends. He was good at composing free verses in Chinese and English. William expressed his joys upon participating Flow Wind workshop activities since it was a space for him to talk with literary friends in poetic languages rather than scientific terminologies.

The following table presents participants' demographic information in detail.

Table 1

Summary of Participants' Characteristics

\begin{tabular}{|c|c|c|c|c|c|c|c|c|c|}
\hline Pariticpants & Gender & $\begin{array}{l}\text { Level of } \\
\text { Study }\end{array}$ & $\begin{array}{l}\text { Year of } \\
\text { Study }\end{array}$ & Major & $\begin{array}{l}\text { English } \\
\text { (L2) Poetry } \\
\text { Writing } \\
\text { Experience }\end{array}$ & $\begin{array}{l}\text { Formal } \\
\text { Education } \\
\text { on English } \\
\text { (L2) Poetry } \\
\text { Writing }\end{array}$ & $\begin{array}{l}\text { Chinese } \\
\text { (L1) Poetry } \\
\text { Writing } \\
\text { Experience }\end{array}$ & $\begin{array}{l}\text { Formal } \\
\text { Education } \\
\text { on Chinese } \\
\text { (L1) Poetry } \\
\text { Writing } \\
\end{array}$ & $\begin{array}{l}\text { Favorite } \\
\text { Topics in } \\
\text { Poetry } \\
\text { Reading and } \\
\text { Writing } \\
\end{array}$ \\
\hline Steve & Male & Undergrad & 3 & $\begin{array}{l}\text { Chemical } \\
\text { engineering }\end{array}$ & Lyric poems & \multirow{4}{*}{ None } & None & \multirow{4}{*}{$\begin{array}{l}\text { Compulsory } \\
\text { education in } \\
\text { China }\end{array}$} & $\begin{array}{l}\text { Human } \\
\text { emotions }\end{array}$ \\
\hline Ziyong & Male & Grad & 1 & Biology & $\begin{array}{l}\text { Template } \\
\text { poems }\end{array}$ & & $\begin{array}{l}\text { Traditional } \\
\text { template } \\
\text { poems }\end{array}$ & & $\begin{array}{l}\text { Home and } \\
\text { culture }\end{array}$ \\
\hline Piaet & Male & Grad & 2 & Physics & $\begin{array}{l}\text { Template } \\
\text { poems }\end{array}$ & & $\begin{array}{l}\text { Contempora } \\
\text { ry free } \\
\text { verses }\end{array}$ & & $\begin{array}{l}\text { Life and } \\
\text { nature }\end{array}$ \\
\hline William & Male & $\begin{array}{l}\text { Grad } \\
\text { (Intern) }\end{array}$ & 2 & Biology & Free verses & & $\begin{array}{l}\text { Template } \\
\text { poems and } \\
\text { free verses }\end{array}$ & & $\begin{array}{l}\text { Oversea } \\
\text { studying } \\
\text { experience }\end{array}$ \\
\hline
\end{tabular}




\section{Researcher's Positionality and Subjectivity}

As the researcher, my shared identity with participants as Chinese and oversea students provided me with chances of examining in greater depth on their voices behind written texts. Meanwhile, my identity as a bilingual (Chinese and English) poetry writer prepared me with knowledge on linguistic features, forms, and techniques of creative writing in both languages and therefore making me more capable of initiating conversations with participants on their perceptions towards the plotting, structuring, and styling of poems. However, I was also aware of the issue of subjectivity due to my positions as workshop organizer and researcher. The good aspect was that we had already known about each other as a group for half a year prior to meeting for research purposes, but in order to keep such relaxed environment for the following poetic practice, to further gain participants' trust and understanding, and to make them largely benefit from this out-of-school literacy activity, I carefully listened to their voice, conducted member checks, and shared my own writings, insights, and stories behind the texts. It was quite observable that our workshop exhibited very low affective filter and all participants kept relaxed and attentive attitudes upon each reading and sharing. For instance, our meeting in December 2015 witnessed a lot of jokes and laughters when participants related their English writings to the recitation on several classical Chinese poems, which indicated that participants perceived Flow Wind as a friendly and creative space to freely share any emergent thoughts with their knowledge on culture, language, and literacy.

\section{Data Collection}

The current study is embedded in the Flow Wind L2 Poetry Workshop activities and data has been collected from November 2015 to March 2016.

The primary data source of this study comes from the participant observation on monthly 3-hour workshop meetings from November 2015 to March 2016 with a total amount of around 15 observational hours. During the meeting, I observe participants' reading, performance, and discussion on their original English poetry, making audio-recording on the entire meeting and taking field notes on specific moment of their dialogic interactions that require further exploration. Based on research questions, I revisit my field notes and audio records, selectively transcribing the records for further analyses.

The secondary data source of the research comes from audio-recorded, semi-structured individual interviews with each participant. The interviews have been taken in December 2015, January and February 2016 with each participant being interviewed twice for 1.5 hours in total. Except for participant Steve who preferred to use English for all interview sessions, the other three participants preferred to use Chinese in combination with Chinese-English code-switching to correspond to interview questions. Interview questions are more directly related to participants' previous meaningful literacy experience as well as their perceptions toward the relationship between such practice and disciplinary studies. The interviews provide me with opportunities of looking into participants' processes of poetic capital accumulation while allowing me to explore their changing perceptions towards out-of-school literacy practices upon joining Flow Wind. A total number of eight interview episodes, around 12 hours, are fully transcribed for analyses.

The third data source is from participants' written artifacts, namely, their original English poems being read or performed during each workshop meeting, representing their linguistic choice, written technique, and decision making in creative literacy practices. A total number of 20 English poems have been collected for research purposes.

The following table helps present a clearer view of data sources. 
Table 2

Summary of Data Sources

\begin{tabular}{|c|c|c|c|c|c|}
\hline Data Source & Content & Frequency & Time & Language & Transcript \\
\hline $\begin{array}{l}\text { Audio-recorded } \\
\text { workshop meetings }\end{array}$ & $\begin{array}{l}\text { English poetry } \\
\text { reading/performing; question } \\
\text { and answer; group discussion }\end{array}$ & 5 times & About 15 hours & $\begin{array}{l}\text { Poetry } \\
\text { reading/performing } \\
\text { in English; poetry } \\
\text { discussion in } \\
\text { English, Chinese and } \\
\text { mixed codes }\end{array}$ & $\begin{array}{l}\text { Partially } \\
\text { transcribed } \\
\text { (discussions in } \\
\text { Chinese are } \\
\text { translated by the } \\
\text { researcher) }\end{array}$ \\
\hline $\begin{array}{l}\text { Audio-recorded, } \\
\text { individual semi- } \\
\text { structured interviews }\end{array}$ & $\begin{array}{l}\text { Previous meaningful literacy } \\
\text { experience; perceptions } \\
\text { toward the relationship } \\
\text { between out-of-school } \\
\text { literacy practice and } \\
\text { disciplinary studies }\end{array}$ & $\begin{array}{l}2 \\
\text { times/partici } \\
\text { pants; } 8 \text { in } \\
\text { total }\end{array}$ & About 12 hours & $\begin{array}{l}\text { Steve used English } \\
\text { throughout the } \\
\text { interviews; other } \\
\text { participants used } \\
\text { mixed codes of } \\
\text { Chinese and English }\end{array}$ & $\begin{array}{l}\text { Fully transcribed } \\
\text { (Conversations } \\
\text { in Chinese are } \\
\text { translated later } \\
\text { by the } \\
\text { researcher) }\end{array}$ \\
\hline $\begin{array}{l}\text { Written texts (English } \\
\text { poems) }\end{array}$ & $\begin{array}{l}\text { Self-reflection; exploration of } \\
\text { nature and life; reflections } \\
\text { toward oversear study; } \\
\text { personal emotion relief }\end{array}$ & $\begin{array}{l}20 \text { pieces in } \\
\text { total }\end{array}$ & None & English & Textual analysis \\
\hline
\end{tabular}

\section{Data Analysis}

Based on Hanauer (2010), the analyses on the features of a corpus of L2 meaningful literacy practices involve "the definition of patterns of frequencies in relation to both linguistic and literary categories of relevance" (p. 39). Thus, for analyzing data collected from the above four major sources, I write a total number of 13 conceptual memos based on observing and participating each workshop meeting and conducting each interview session. The memos effectively help me identify emergent patterns, trends, insights, and themes derived from participants' interactive dialogues that reflect processes of their poetic capital accumulation. For analyzing and coding textual data of participants' written poems and online discussion excerpts, I mainly refer to Hanauer's (2010) poetic research methodology that emphasizes the characteristics in different poetry writing procedures as well as writer's identity and individuality, focusing on the exploration of participants' textual voices that demonstrate their accumulation of capitals.

After revisiting empirical data, refining and grouping the initial open codes, a total number of 30 analytical codes are framed within the categories of "interdisciplinarity, meaning of poetic practices, identity, poetry as a multimodal genre, poetry writing processes, poetic genres, audience, poetry writing techniques, poetic features, gender, humanizing research" have been generated and presented in the Coding Table attached as Appendix.

\section{Findings}

\section{Research Question 1: What Are the Characteristics of Flow Wind Out-of-School L2 Poetry Practice?}

Different from classroom-based L2 meaningful literacy practices previously reviewed in Dai's (2015), Iiad's (2010), Saito's (2008), and Stewart's (2010) cases, in Flow Wind L2 Poetry Workshop, participants do not have specific readings or themes assigned prior to English poetry composition. From the content analysis on participants' 20 pieces of original English poems, seven are closely related to self-reflection and emotional relief; six are more about writers' intimate observations toward the beauty and power of nature; four are related to participants' oversea lives and studies; and the rest three speak for culture shock. However, in most writings, 
it is not difficult to read a remixed theme of reflecting the emotional selves projected in powerful nature and newly adapted culture.

For instance, in William's short poem, Self, he wrote, "I found no city lights/Nourishing such pouring rain/In pitch-darkness/I couldn't see myself/Sharpened thunders danced/Between them I found only/Myself walking, half-smashed/In glaring flames" (slashes indicate the stops between verses). In our group discussion on this poem, William explained the context for writing: “...there was suddenly a thunderstorm. I was walking along a pitch-dark road, and to my surprise, there was no street lights. At that moment, I felt very lonely-I didn't drive, I walked; I didn't belong to this city, I was foreign...It was the first time I came to a foreign country cross the Pacific Ocean all alone-I have never been this far from my family-it was hard for me to imagine and experience all of this" (Group discussion, January 13, 2016, translated). William's remarks on his oversea studying and living experiences resonated with the other three participants very well: Upon coming to a foreign, Western country, they experienced cultural shock, emotional loneliness, and communicative barriers in terms of L2 proficiency. Especially when walking along the dark street in thunderstorm with no companies, the sense of loneliness and fear naturally increased. "Suddenly, there was lightening", said William, "and I saw myself - my shadow on the ground under the lightening - I saw my physical figure clearly. But by saying 'I couldn't see myself', I meant all of a sudden, there was no lightening, and everything went back to pitch-darkness with the sound of pouring rain: at that very point, I felt so lost-dark came back and I was still walking to somewhere or nowhere? I mean that I couldn't tell my future-everything, everyone was so new to me: I lost my self in such new environment" (Group discussion, January 13, 2016, translated). Based upon William's narratives, participants shared their personal experiences and feelings within the group: They could not tell how much they missed home and old friends yet clearly knew that their families spend a lot, emotionally and materially, to support them to pursue advanced studies in US. Thus, they spent no efforts in making their journey meaningful, making their families and friends proud of them. Meanwhile, participants reflected that they constantly felt great pressure of involving themselves into local and institutional communities while undergoing the trajectory of being academically and socially acculturated.

Having doubts and concerns about self and future, participants started to write their feelings in a second language with creative, figurative, and emotional features and gradually became more willing to share their L2 voices within the space of out-of-school literacy practice:

"You have companies experience similar situations and they will support you to get rid of difficult times" (Ziyong, group discussion, March 4, 2016, translated); "You will always have some time to make reflections on yourself, to rediscover yourself. And I guess what makes us different, what makes us come together is that we dare to write such pains down on the paper, to make it concrete instead of keeping silent; we put it in creative languages and imaginative ways: I think that we are gifted in using poems as tools to outlet our emotions" (Piaet, group discussion transcript, March 4, 2016, translated).

From the above group talks, it was not hard to see that participants in Flow Wind gradually trusted one another and felt relaxed in sharing their concerns; they were generous in providing others with emotional supports, appreciating others' creativity and aesthetics in using an L2 to voice their experience and feeling. Within this space, participants also felt free to identify themselves as owners of a second language and creativity, because different from L2 classrooms, where discussions and revisions on grammatical appropriateness weighted a lot, participants in Flow Wind out-of-school context talked more about their thoughts, feelings, and voices behind texts, constantly connecting their previous experience with current living 
and studying conditions. Thus, instead of labeling themselves as English learners, participants were more acknowledged themselves as English poetry writers: "After our [original L2 poetry] reading and discussion, I have more confidence in my English ability, because you guys embrace my poems by pointing out several outstanding verses I wrote, such as 'Olentangy River...you begin to murmur/Decorated with green fur/You join in bird's concert': I am encouraged to write more and I sense that you like the way I use rhyming and personification... I think that maybe one day I will share the poem Olentangy River with my English teacher. I never think of that before" (Piaet, interview, January 5, 2016, translated).

Similarly, when Ziyong shared his poem, I Wish I Could Become: "I wish I could become/I wish I could/become a tree/I bloom when I am happy/I shed leaves when I am in sorrow", he was praised by others on the simplicity of language, contrastive figure of speech, written techniques of personification and de-personification, and rich meanings behind texts:

"I hesitated a lot if I am going to share it, because I think that the language is naïve" (Ziyong, interview, February 5, 2016, translated). But William, Piaet, and Steveem braced its simplicity and commented that it was a good poem because the underlying meanings of feeling tired about being a sophisticated man, being bored of pleasing others that sacrificed self-pleasure or self-esteem, and hoping for simple, natural life had been well presented within the limited textual space. Thus, participants agreed upon that simplified poetic language or structure did not equal to simplicity in emotional revealing, but rather, meanings were socially constructed through negotiations, which showed participants' acknowledgement on the social nature of poetic practices. Moreover, Ziyong and William insisted on not revising their initial drafts, because they believed that though revised texts might present audience with greater linguistic diversity with more exquisite languages, the revisions changed the emotions the writers had at the moments of writing.

Another salient characteristic of Flow Wind out-of-school poetry practice was that L2 poems were composed and presented in different forms. Among the 20 English poems, there were 16 pieces of free verses, two pieces of template poems, and another two pieces of lyric poems. Steve was the one who wrote lyric poems and performed them with his guitar.

In the poem $A$ Girl, he revealed complicated personal feelings towards a newly started relationship and by performing it with his guitar, the subtle emotions between lines were amplified and dramatized: "You make me cry, you left me twice/You offer me a bargain, you let me die/You lead me to the light, you dropped me to side/You saved me out of water, you let me dry/Let me dry" (Excerpts, slashes indicate stops between lines): Steve's orality with musical instrumental concordance made his language, voice, and body skillfully orchestrated to provide a dynamic and striking oral performance (Newsfield \& D'adbon, 2015); singing the poem out with guitar, Steve unfolded his inward feelings through different channels: the written words "express[ed] sadness and helpless" (Steve, group discussion, December 26, 2015) while the guitar-assisted singing with melodic, rhyming tones "give[gave] senses of nostalgia and hard choices" (Steve, group discussion, December 26, 2015). Steve also claimed that singing his lyric poems gradually became a hobby: "It's just natural for me [to sing them], especially with the repetitive chorus part. It is for me kind of dry if I just read it over and over again" (Steve, group discussion, December 26, 2015).

Therefore, the major characteristics of Flow Wind out-of-school poetry practices could be synthesized as the following: (1) Since there were no assigned themes for writing, participants wrote more about their personal emotions, self-reflections, and self-positionality by using first and second pronouns to indicate their changing relationship with people, culture, and nature; a remixed theme of reflecting on oversea study, life, and 
cross-cultural experiences was generally found in writing samples; (2) participants' writing and performance without classroom constraints indicated that L2 poetry could be presented in multiple forms through combined modalities; (3) participants felt free to discuss and comment on each other's writings without considerations on grades or academically associated evaluations as they had in classroom settings and therefore being more able to provide each other with sincere feedback, emotional and social supports; and (4) participants were not limited to the drafting and redrafting procedures as suggested in process-oriented L2 writing classrooms and thus feeling free in making their own decisions as L2 poetry writers on linguistic choice, formatting, or structuring.

\section{Research Question 2: What Are the L2 Poetry Writers' Perceptions Towards the Relationship Between Their Out-of-School Creative Literacy Practice and Major-Related Studies?}

To begin with, as presented in the first finding section, participants felt that Flow Wind was a space to relieve their academic pressure while providing them with opportunities of making literacy friends who emotionally and socially supported one another in their journey of academic acculturation.

Besides agreeing upon the therapeutic function of Flow Wind, participants found a reciprocal linkage between their out-of-school, self-regulated L2 poetic practices and their in-school, disciplinary studies: Through poetry writings and discussions, it was obvious that participants' scientific-oriented disciplinary knowledge and thinking patterns could be perceived as embedded, institutionalized capital that facilitated their creative literacy practice while in turn, their creative writings provided them with inspiration in major-related studies, cultivating their aesthetic capacity and imagination in academically-oriented lab experiment design and conduct.

In this space, participants' disciplinary knowledge was perceived as an important source of their poetic capital accumulation, along with other resources derived from their L1 literature studies, L2 learning and practices, and reflections towards everyday life.

According to the analyses on participants' group discussions (workshop meetings and online conversations), individual interviews, and written texts, it was the rigorous reasoning skill that participants' acquired from their longitudinal Science, Technology, Engineering, and Mathematics (STEM) studies that largely shaped their process of wording, formatting, structuring, and interpreting an L2 poem, making them more confident and rational in sharing their poetry writings within the group.

As stated in participant description, Ziyong, Steve, William, and Piaet were all science and engineering majors who spent a lot of time in labs and communicated with peers in major-related terminologies upon attending college. The old stereotype indicated that science and poetry were independent and polarized entities (Hayakawa, 1944): Science is associated with scientific languages and therefore was considered as intellectual, logical, and rigorous; while poetry on the contrary, with its dynamic, imaginative, and artistic languages, was always regarded as emotional and individual. However, it is obvious from this study that poetry belongs to the general public with people having different fields of studies or specialties.

Among the 30 codes on L2 meaningful poetry practices (see Appendix), the code of "poetic reasoning" spoke for how L2 poetic practices and scientific studies were closely related in this research context. "Poetic reasoning" in this space was defined as,

The influence of participants' skill of rigorous scientific reasoning acquired from their longitudinal disciplinary STEM studies in China and US on their autonomous L2 poetry writing practices in out-of-school contexts; the reasoning 
skill that demonstrated participants' perception towards accuracy and precision in their linguistic choices, their rationality of creating and adding meaning to figurative L2 expressions, and their aesthetics and artistry in projecting rich emotions and feelings from brain to page and from page to stage. (see Appendix)

For example, in interpreting the contrastive linguistic feature of Steve's lyric poetry, A Girl, he claimed that "I think this way of making contrasts in my lyric poem writing and thinking [e.g. "You lead me to the light, you dropped me to side", lyric poem excerpt] is largely derived from my major study [chemical engineering], because my major requires a lot of point-wise and polarized understanding towards specific quantitative variables...contrasts in lyric poem writing dramatize my inward feelings and make them more visible and approachable to listeners [audience]" (Steve, interview, December 31, 2015): It was revealed from the participant's own telling that he intentionally transferred his disciplinary-oriented, polarized thinking pattern to lyric poem writing, and it was largely appreciated by other participants with comment like "the contrastive words and phrases sound very powerful in telling the narrator's uneasy feeling, depicting a vivid picture of the discursive, unpredictable nature of his emotional journey" (Piaet, group discussion, December 26, 2015, translated). This brief sample indicated that such transferrable reasoning skill from STEM study to L2 poetry writing, being perceived as Steve's accumulated poetic capital, largely facilitated his plotting, wording, and meaning-making processes in lyric poetry composition.

From textual analysis on Piaet's English poem, Olentangy River, it was obvious that he paid special attention to precision in L2 poetry writing in terms of the number of words, punctuation, repetition, tense, rhyming, contrasting, and personification:

"Olentangy River, / Olentangy River! / How quiet once you were; / Now spring is coming, / And you begin to murmur; / Decorated with green fur, / You join in bird's concert; / In a sunshine morning, / You have melt my heart. / Olentangy River, / Olentangy River! / How mad once you were; / Now autumn is going, / You become more mature. / Reflecting thousands of color, / You become a painter; / In a bright noon, / You attract every passer" (Slashes indicate stops between lines).

The poem was composed of two stanzas that adopted identical template: "repetition of the name of the natural scene + feature of its past natural status + current changes in the writer's view + writer's projection in nature". From the linguistic and metaphoric features, the template showed "repetition of the noun + how initiated exclamation verse with personification + now initiated descriptive verses with personification + specific time phrase + interactive descriptions with personification". During the interview with Piaet, he mentioned that structured poems with rhyming features, instead of free verses, made him feel safe in calling it a poem; he held that it was his studies (Physics) made him believed that poetry, like Mass in the universe, had certain structures in form but expressed free spirits in content and he was seeking for the symmetry in poems that helped him equally voicing contrastive thoughts. Meanwhile, very much like Steve, Piaet felt delightful in reading the rhyming parts which created melodic tones that resonated with the flow of the his emotions.

Another data sample under the code of "poetic reasoning" spoke for the interdisciplinary feature of L2 poetry practice was that participant Ziyong (Biology major) mentioned in the first session of our interview, " $I$ am recently thinking about writing a poem in the format of the DNA structure. Because in our fields of study, DNA structure is stable, sustainable, and I personally think that it is beautiful...Designing a poetry writing format in DNA structure should take the placement of words, word sounds and meanings into careful consideration to make such a new format reasonable. Would that be cool and interesting, giving readers visual freshness? Would such poem felt differently when being read, either aloud or silently" (Ziyong, interview, 
February 21, 2016, translated)". Ziyong's intentional linkage between his disciplinary knowledge on DNA structure and the formatting of an L2 poem showed his transferred aesthetic capacity from scientific encounter to creative writing with strong awareness audience.

In Donald Hall's interview with Marianne Moore (1887-1972), an established American Modernist poet and the winner of 1952 Pulitzer Prize for Poetry, Miss Moore confidently reflected on the impact of scientific laboratory experience on shaping her lifelong respect towards descriptive precision in her poetry and other literacy practices: "I found the biology courses-minor, major, and histology-exhilarating. I thought, in fact, of studying medicine. Precision, economy of statement, logic employed to ends that are disinterested, drawing and identifying, liberate - at least have some bearing on - the imagination, it seems to me" (Marianne Moore being interviewed in Women Writers at Work, p. 24). In this way, poetry and science present in reciprocal connections as suggested by the first-hand data presented in this study, since disciplinary studies, such as mathematics and biology, fosters the reasoning skills in making poetic composition a more rationale literacy practice; in return, poetic practice cultivates people's imagination and aesthetic capacities that might inspire their disciplinary studies.

For participants in this study, the out-of-school L2 poetry practice influenced their major-related studies mainly from the following aspects. First of all, their poetry writing and sharing cultivated participants' ownership of an L2, building up their confidence in English writing as a whole. As Piaet mentioned, "I used to worry about my English language proficiency in writing lab reports, academic papers, or academic forum discussions. Regular English poetry writing practice and discussion with you guys made me see that I am actually not a bad English writer; I am not only good at presenting statistics, but also good at describing things and telling stories. So I can feel that I have more confidence and feel less fearful of making mistakes in academic writings nowadays" (Piaet, interview, February 9, 2016, translated). Then, during my interview with Ziyong, I talked about Piaet's reflections presented above and ask Ziyong if that commentary resonated with him. Ziyong confirmed Piaet's thoughts by adding that "Writing poetry in English is actually very challenging for me, but now I tend to keep up the pace of writing at least one per month, from which I find I tend to pay more attention to details... in my first poem sharing, I write something like 'I shed leaves when I am in sorrow' and it is very general feelings; but as you may read from my recent one named New York Stranger, I describe the person as 'He came, a scientist/ his smile, / his clothes, bag, and shoes, / all scientists', / in sort of humor with rationale, / sort of out-of-data fashion, / with a contemporary taste of arty thing'... I force myself to write details about the person's appearance instead of general descriptions, and of course, details tell more" (Ziyong, interview, February 21, 2016, translated). Thus, the participant's awareness on detailed information cultivated his observational abilities and sensitivity in everyday life, which might have positive influences on his disciplinary studies in the long run.

\section{Discussion and Conclusion}

In the space of Flow Wind out-of-school L2 meaningful creative literacy practice, participants were reported to enjoy workshop meetings, in which they read, performed, and discussed their original English poems, talking about their experiences and stories behind the creative texts and providing each other with emotional and sociocultural supports regarding their oversea lives and disciplinary studies. Regular monthly workshop meetings left participants in Flow Wind with time and energy to make self-reflections, build up literary friendship, and learn from other people on their attitudes towards life, aesthetic capacities in L2 
learning, and connections made between poetic practices and disciplinary studies. In this sense, out-of-school meaningful literacy practice positioned participants' knowledge, needs, and expectations as the center of all literacy activities. Moreover, compared to classroom-based creative literacy practice, the out-of-school one apparently assigned participants with more freedom in choosing written topics, languages, structures, and interactive formats, which allowed more authentic representations of participants' voices, emotions, experiences, attitudes, beliefs, and opinions. With little grading pressure, participants in out-of-school spaces took the most advantage of their participatory opportunities to express themselves, which in return, largely benefited both of their social and cognitive growths.

Therefore, out-of-school meaningful literacy practice serves as an important complementary space in addition to classroom-based practice for learners to advance their understandings towards the meaning and practicality of learning a second language; it also helps cultivating participants' ownership of a second language and authorship of creativity.

Besides, without classroom constraints, participants in out-of-school spaces are encouraged to perform their writings in multiple creative ways with the application of various tools or mediating artifacts, such as musical instrument in the case of Flow Wind, which further fosters their ownership of creativity and artistry, and demonstrates that literacy practices can be approached in multiple modalities, such as orality and musicality, other than solely textual representation. Thus, the promotion of out-of-school meaningful literacy practice is out of the fact that it is more flexible and dynamic in nature, which allows a lot more possibilities in making meaning towards language learning and everyday life.

In addition, by temporarily stepping out of specific disciplinary studies and L2 classrooms, participants in self-regulated, out-of-school L2 literacy practices are encouraged to have an etic view of the potential linkages between their language/literacy practices and major-related works; they are given freedom of talking about their perceptions towards such relationship in creative manners without academic pressure, whereas in L2 classrooms that primarily address issues of second language acquisition, the limitation of reading and writing materials or teachers' focus on students' average language proficiency level might constrain L2 learners' thoughts on bridging their language/literacy practices with disciplinary studies. Moreover, reflections towards the relationship between language/literacy practices and major-related studies further demonstrate how embedded and institutionalized capitals (Bourdieu, 1986) affect language learning and how literacy practices in turn cultivate the sense of creativity and aesthetics in disciplinary knowledge acquisition. Therefore, the proposal of encouraging language learners to take use of their resources from disciplinary studies and everyday life while positively seeking for interdisciplinary connections throughout their learning processes is important because it cultivates language learners' cognitive growths from multiple meaningful aspects instead of from one single channel, making language learners become whole persons with networks of interdisciplinary knowledge.

Though Flow Wind L2 Poetry Workshop stands out as only one single case that demonstrates the possibilities and success of out-of-school meaningful literacy practice in creative genres, the organizational model is applicable to various contexts with L2 learners coming from different sociocultural backgrounds and sharing similar interest in literacy practices. After all, the primary concern for humanized meaningful literacy research is to place language learners at the center of all practices while making learners most benefit from research projects and grow as wholesome persons. 


\section{References}

Bourdieu, P. (1986). The forms of capital. In J. Richardson (Ed.), Cultural theory: An anthology (pp. 81-93). Westport, CT: Greenwood.

Cahnmann, M. (2006). Reading, living, and writing bilingual poetry as scholARTistry in the language arts classroom. Language Arts, 83(4), 342-352.

Craig, A., \& Dubois, S. (2010). Between art and money: The social space of public readings in contemporary poetry economies and careers. Poetics, 38(5), 441-460.

Dai, F. (2015). Teaching creative writing in English in the Chinese context. World Englishes, 34(2), 247-259.

Elting, S., \& Firkins, A. (2006). Dramatizing poetry in the second language classroom. English Teaching, 5(3), 127-136.

Gregory, H. (2008). The quiet revolution of poetry slam: The sustainability of cultural capital in the light of changing artistic conventions. Ethnography and Education, 3(1), 63-80.

Hanauer, D. (2012). Meaningful literacy: Writing poetry in the language classroom. Language Teaching, 45(1), 105-115.

Hanauer, D. I. (2010). Poetry as research: Exploring second language poetry writing. Pennsylvania, PA: John Benjamins Publishing.

Hayakawa, S. (1944). Poetry and science. ETC: A Review of General Semantics, 1(4), 216-224.

Hyland, K. (2007). Genre pedagogy: Language, literacy and L2 writing instruction. Journal of Second Language Writing, 16(3), 148-164.

Iida, A. (2008). Poetry writing as expressive pedagogy in an EFL context: Identifying possible assessment tools for haiku poetry in EFL freshman college writing. Assessing Writing, 13(3), 171-179.

Iida, A. (2010). Developing voice by composing haiku: A social-expressivist approach for teaching haiku writing in EFL contexts. English Teaching Forum, 48(1), 28-34.

Kramsch, C. (2006). Preview article: The multilingual subject. International Journal of Applied Linguistics, 16(1), 97-110.

Leal, P. (2015). Connecting reading and writing using children's literature in the university L2 classroom. Reading in a Foreign Language, 27(2), 199-218.

Lee, H. (2013). The reading response e-journal: An alternative way to engage low-achieving EFL students. Language Teaching Research, 17(1), 111-131.

Myskow, G., \& Gordon, K. (2010). A focus on purpose: Using a genre approach in an EFL writing class. ELT Journal, 64(3), 283-292.

Newfield, D., \& D'abdon, R. (2015).Reconceptualising poetry as a multimodal genre. TESOL Quarterly, 49(3), 510-532.

Newman, M., \& Hanauer, D. (2005). The NCATE/TESOL teacher education standards: A critical review. TESOL Quarterly, 39(4), 753-763.

Ostrow, J., \& Chang, L. (2012). I'm a poet? International doctoral students at a US university participate in a creative writing workshop. TESOL Journal, 3(1), 48-64.

Saito, A. (2008). Between me and the world: Teaching poetry to English language learners. Teaching Artist Journal, 6(3), 197-208.

Stewart, M. (2010). Writing with power, sharing their immigrant stories: Adult ESOL students find their voices through writing. TESOL Journal, 1(2), 269-283. 
Appendix: Coding Table

\begin{tabular}{|c|c|c|c|c|c|}
\hline \multicolumn{2}{|c|}{ Code } & \multirow{2}{*}{\begin{tabular}{|l|} 
Explanation \\
How do participants major studies \\
influence their poetic practices and \\
vice versa?
\end{tabular}} & \multirow{2}{*}{ Categorization } & \multirow{2}{*}{ Frequency } & \multirow{2}{*}{$\begin{array}{l}\text { Example } \\
\text { "I think this way of writing and thinking about things is very useful in my } \\
\text { major study, because my major requires a lot point-vise understanding" } \\
\text { (Steve, interview transcript, December } 31,2015 \text { ). }\end{array}$} \\
\hline 1 & Interdisciplinarity & & & & \\
\hline 2 & Poetic reasoning & $\begin{array}{l}\text { Participants' decision making in } \\
\text { poetry writing at lexical, phrasal, } \\
\text { metaphorical, and structural levels } \\
\text { reveals their logic and rationality in } \\
\text { composing creative texts; }\end{array}$ & Interdisciplinarity & 25 & $\begin{array}{l}\text { "Both two categories of reasoning require people to make logical } \\
\text { connections: in poetic reasoning, poets on one hand, make rationale } \\
\text { projections of images in minds to dynamic word and phrasal expressions on } \\
\text { page; on the other hand, poets make textual communication with their readers } \\
\text { through resonating and echoing across time and space" (Analytic Memo, } \\
\text { Poetic Reasoning, January 4, 2016). }\end{array}$ \\
\hline 3 & Poetic capital & $\begin{array}{l}\text { Participants' investment of time and } \\
\text { energy on poetry-related reading and } \\
\text { writing activities at different stages } \\
\text { in their lives as resources for their } \\
\text { current poetic practices; }\end{array}$ & Interd & 30 & $\begin{array}{l}\text { Families read these popular traditional Chinese poems to us, engaging us to } \\
\text { learn pinyin and simple Chinese characters, and encouraging us to memorize } \\
\text { poetic lines which were rather short but full of rhyming and melodic tones of } \\
\text { alliteration, assonance, and consonance (Analytic Memo, Poetic Capital, } \\
\text { February 15, 2016). }\end{array}$ \\
\hline 4 & $\begin{array}{l}\text { Ownership of the } \\
\text { English language }\end{array}$ & $\begin{array}{l}\text { What does writing poetry in English } \\
\text { mean to Chinese participants? Does } \\
\text { English poetry writing reshape } \\
\text { participants' perceptions towards the } \\
\text { language itself and Western culture? }\end{array}$ & $\begin{array}{l}\text { Meaning of poetic } \\
\text { practices }\end{array}$ & 9 & $\begin{array}{l}\text { “...there is definitely one-to-one correspondence between English and } \\
\text { Chinese translation, but I just think...thinking in English words will more } \\
\text { directly...express my feeling at the moment" (Steve, interview transcript, } \\
\text { November } 25,2015) \text {. }\end{array}$ \\
\hline 5 & $\begin{array}{l}\text { Ownership of } \\
\text { creativity }\end{array}$ & $\begin{array}{l}\text { What does writing in creative } \\
\text { manners mean to participants? Do } \\
\text { poetic practices improve their } \\
\text { aesthetic capacities in general? }\end{array}$ & & 13 & $\begin{array}{l}\text { “... why not write a poem on paper in the format of the DNA structure? } \\
\text { Would that be cool and interesting, giving readers visual freshness? Would } \\
\text { such poem felt differently when being read" (Analytic Memo, Poetic } \\
\text { reasoning, February 21,2016). }\end{array}$ \\
\hline 6 & $\begin{array}{l}\text { Pressure } \\
\text { relieving/ } \\
\text { Emotional } \\
\text { relieving }\end{array}$ & $\begin{array}{l}\text { Poetic practices enable participants } \\
\text { to get rid of the repression, violence, } \\
\text { and passivity, providing them with } \\
\text { free and peaceful spaces that } \\
\text { facilitate agency, a tolerance of } \\
\text { difference, and the development of } \\
\text { creativity (Stein \& Newfield, 2006); }\end{array}$ & & 20 & $\begin{array}{l}\text { “在我第二次抑郁之后, 我选课特别少, 然后我写了第二部小说。这部小 } \\
\text { 说书写过程中, 有非常多地修改。我觉得这一部是我特别满意的作品。 } \\
\text { 其中也有比较多的诗文呈现。其实写这本书, 我回忆了很多之前非常喜 } \\
\text { 欢的读本” (B (Billy), interview transcript, January 19, 2016). }\end{array}$ \\
\hline 7 & $\begin{array}{l}\text { Poetic identity } \\
\text { (Hanauer, 2010) }\end{array}$ & $\begin{array}{l}\text { "Participants' subject position on } \\
\text { autobiographical events and } \\
\text { experiences expressed through the } \\
\text { focusing potential of literary } \\
\text { language resulting from a specific } \\
\text { physical and discursive context of } \\
\text { writing" (Hanauer, 2010, p. 62); }\end{array}$ & & 18 & $\begin{array}{l}\text { “(3) a Chinese poet who is gifted in connecting his very personal emotions in } \\
\text { mind with poetic and artistic expressions on paper, and whose poetic } \\
\text { discourses reach a wide range of audience who share similar living and } \\
\text { studying experience with him" (William, Analytic Memo, November 30, } \\
\text { 2015). }\end{array}$ \\
\hline & $\begin{array}{l}\text { Collective } \\
\text { identity } \\
\text { (Hanauer, 2010) }\end{array}$ & $\begin{array}{l}\text { Identities co-exist with the poetic } \\
\text { identity; the social nature of } \\
\text { participants' multilayered identity; }\end{array}$ & & 19 & $\begin{array}{l}\text { "Ph.D. in the being, science major student, oversea student, L2 learner and } \\
\text { user, student poet, son-family" (Pieat, Analytic Memo, February 15, 2016). }\end{array}$ \\
\hline
\end{tabular}




\begin{tabular}{|c|c|c|c|c|c|}
\hline \multicolumn{2}{|c|}{ Code } & Explanation & \multirow[b]{2}{*}{ Categorization } & \multirow{2}{*}{ Frequency } & \multirow[b]{2}{*}{$\begin{array}{l}\text { Example } \\
\text { "when I see the growing greens along the river, and in the morning, breathing } \\
\text { in fresh air, I feel the strength growing in my muscles and minds; I have very } \\
\text { positive attitudes towards the new year-being positive about friendship and } \\
\text { my studies" (Piaet, interview transcript, translated, February 15, 2016). }\end{array}$} \\
\hline 9 & Voice & $\begin{array}{l}\text { What participants feel, say, } \\
\text { understand, and interpret about the } \\
\text { world they live in via the application } \\
\text { of creative languages with innovative } \\
\text { forms of writing and sharing? }\end{array}$ & & & \\
\hline 10 & Multimodality & $\begin{array}{l}\text { (Poetic) Language, voice, and body } \\
\text { are orchestrated skillfully to provide } \\
\text { a dynamic and striking written or } \\
\text { oral performances (Newfield \& } \\
\text { D'adbon, 2015); }\end{array}$ & $\begin{array}{l}\text { Poetry as a } \\
\text { multimodal genre } \\
\text { (Newfield \& } \\
\text { D'abdon, 2015) } \\
\end{array}$ & 8 & $\begin{array}{l}\text { "I performed some classic traditional Chinese poems by singing them out } \\
\text { with my hometown dialect, the mountain songs and the tones of HuaGu Xi, } \\
\text { which I found very interesting. I sang those classic poetry based on my } \\
\text { understanding towards the poetry..." (ZY, interview transcript, translated, } \\
\text { December 30,2015). }\end{array}$ \\
\hline 11 & $\begin{array}{l}\text { Lyric poem and } \\
\text { performance }\end{array}$ & $\begin{array}{l}\text { A combination of the participant's } \\
\text { creative writing, orality, and } \\
\text { non-verbal performances; }\end{array}$ & $\begin{array}{l}\text { Poetry as a } \\
\text { multimodal genre } \\
\text { (Newfield \& } \\
\text { D'abdon, 2015) } \\
\end{array}$ & 10 & $\begin{array}{l}\text { "it's just natural for me to sing them, especially with the repetitive chorus } \\
\text { part. It is for me ...is kind of dry if I just read it over and over again. I don't } \\
\text { know, maybe it's just a hobby, a habit" (Steve, interview transcript, } \\
\text { November 25, 2015). }\end{array}$ \\
\hline 12 & $\begin{array}{l}\text { Online poetic } \\
\text { interaction }\end{array}$ & $\begin{array}{l}\text { How do participants interact with } \\
\text { one another via the online poetry } \\
\text { communicative platform? }\end{array}$ & $\begin{array}{l}\text { Poetry as a } \\
\text { multimodal genre } \\
\text { (Newfield \& } \\
\text { D'abdon, 2015) }\end{array}$ & 6 & $\begin{array}{l}\text { “Let’s read William's following: } \\
\text { 我想变 我想变 } \\
\text { 我想变成一把菜刀 } \\
\text { 开心时, 切菜 } \\
\text { 不开心时, 切手”(Online interaction download, February 1, 2016). } \\
\end{array}$ \\
\hline 13 & $\begin{array}{l}\text { Activation/ } \\
\text { Motivation } \\
\text { (Hanauer, 2010) }\end{array}$ & $\begin{array}{l}\text { Experiential and/or associative } \\
\text { process that triggers the writing } \\
\text { process (Hanauer, 2010); }\end{array}$ & $\begin{array}{l}\text { Poetry writing } \\
\text { processes }\end{array}$ & 17 & $\begin{array}{l}\text { "When I feel upset, or going out having fun with friends, or walking alone in } \\
\text { some quiet places by myself, or even after drinking, and when some readings } \\
\text { resonate me so well" (ZY, interview transcript, December 18, 2015). }\end{array}$ \\
\hline 14 & $\begin{array}{l}\text { Discovery } \\
\text { (Hanauer, 2010) }\end{array}$ & $\begin{array}{l}\text { Reveals a deeper meaning or } \\
\text { understanding of the initial written } \\
\text { texts (Hanauer, 2010); }\end{array}$ & $\begin{array}{l}\text { Poetry writing } \\
\text { processes }\end{array}$ & 20 & $\begin{array}{l}\text { “因为是借着闪电忽隐忽现, 一会看得到自己, 一会看不到自己一来表 } \\
\text { 达自己对自己地认识, 有时候很能清楚地看清自己, 缺点或优点, 有时 } \\
\text { 候却容易迷失, 连自己都不知道自己会去哪里, 要追求什么。”(William, } \\
\text { interview transcript, December } 29,2015) \text {. }\end{array}$ \\
\hline 15 & $\begin{array}{l}\text { Permutation } \\
\text { (Hanauer, 2010) }\end{array}$ & $\begin{array}{l}\text { Revision stages of poetry writing } \\
\text { (Hanauer, 2010); }\end{array}$ & $\begin{array}{l}\text { Poetry writing } \\
\text { processes }\end{array}$ & 5 & $\begin{array}{l}\text { "I do have my poems revised based on other's suggestions because I find that } \\
\text { there are a number of poets whose written techniques and understandings } \\
\text { towards poetic and historical knowledge are much better than mine." (ZY, } \\
\text { interview transcript, translated, December } 18,2015) \text {. }\end{array}$ \\
\hline 16 & $\begin{array}{l}\text { Finalization } \\
\text { (Hanauer, 2010) }\end{array}$ & $\begin{array}{l}\text { The decision of finishing rewriting or } \\
\text { redrafting and to view the text as a } \\
\text { finished object (Hanauer, 2010); }\end{array}$ & $\begin{array}{l}\text { Poetry writing } \\
\text { processes }\end{array}$ & 5 & $\begin{array}{l}\text { “改到我自己欣赏起来觉得, 已经上比较好同时语言也优雅, 体现诗性 } \\
\text { 就好了” (William, interview transcript, translated, December 30, 2015). }\end{array}$ \\
\hline 17 & $\begin{array}{l}\text { Autobiographical } \\
\text { writing } \\
\text { (Hanauer, 2012) }\end{array}$ & $\begin{array}{l}\text { Employ writing that utilizes memory, } \\
\text { imagination and personal experience } \\
\text { to explore and understand the self } \\
\text { (Hanauer, 2012); }\end{array}$ & $\begin{array}{l}\text { Poetic genres } \\
\text { (Meaningful } \\
\text { literacy practice, } \\
\text { Hanauer, 2012) }\end{array}$ & 13 & $\begin{array}{l}\text { "I felt the darkness, as it was the first time I came to a foreign country cross } \\
\text { the Pacific Ocean all alone-I have never been this far from my family-it } \\
\text { was hard for me to imagine all of this years ago. Suddenly, there was } \\
\text { lightening. And I saw myself" (William, interview transcript, translated, } \\
\text { December 30, 2015). }\end{array}$ \\
\hline
\end{tabular}




\begin{tabular}{|c|c|c|c|c|c|}
\hline \multicolumn{2}{|c|}{ Code } & \multirow{2}{*}{\multicolumn{2}{|c|}{\begin{tabular}{|l|l|} 
Explanation & Categorization \\
Activates and elicits writers & Poetic genres \\
emotional responses, endorses the & (Meaningful \\
expression of personal feelings & literacy practice, \\
(Hanauer, 2012); & Hanauer, 2012) \\
\end{tabular}}} & \multirow{2}{*}{ Frequency } & \multirow{2}{*}{$\begin{array}{l}\text { Example } \\
\text { “.... and everything went back to pitch-darkness with the sound of pouring } \\
\text { rain: at that very point, I felt so lost—-dark came back and I was still walking } \\
\text { to somewhere, to nowhere?" (William, interview transcript, translated, } \\
\text { December } 30,2015) \text {. }\end{array}$} \\
\hline 18 & $\begin{array}{l}\text { Emotional writing } \\
\text { (Hanauer, 2012) }\end{array}$ & & & & \\
\hline 19 & Personal insights & $\begin{array}{l}\text { Integrate a reflective process that } \\
\text { leads to a deepened appreciation and } \\
\text { understanding of personal } \\
\text { experience, and ultimately } \\
\text { understand the human condition } \\
\text { (Hanauer, 2011); }\end{array}$ & $\begin{array}{l}\text { Poetic genres } \\
\text { (Meaningful } \\
\text { literacy practice, } \\
\text { Hanauer, 2012) }\end{array}$ & 19 & $\begin{array}{l}\text { "...yet in the spring, the river likes animals, awakes from habitation and } \\
\text { sunshine melts the frozenness and I can feel its flow and sparkling sun lights } \\
\text { the river reflects on its mirror surface" (Piaet, interview transcript, translated, } \\
\text { March } 1,2016) \text {. }\end{array}$ \\
\hline 20 & $\begin{array}{l}\text { Authentic public } \\
\text { access } \\
\text { (Hanauer, 2012) }\end{array}$ & $\begin{array}{l}\text { Situate writing within a social } \\
\text { process of presenting personally held } \\
\text { beliefs, understandings and feelings } \\
\text { to others beyond the language } \\
\text { classroom to people and } \\
\text { communities who are of significance } \\
\text { to the writer (Hanauer, 2012); }\end{array}$ & Audience & 7 & $\begin{array}{l}\text { "...because I hope that my poetry not only being written for myself, but also } \\
\text { I have expectations from the audience. I hope that they can have better } \\
\text { understandings towards what I have written" (ZY, interview transcript, } \\
\text { December } 18,2015 \text { ). }\end{array}$ \\
\hline 21 & Poetry emulation & $\begin{array}{l}\text { Writing poems from imitating } \\
\text { others' works to developing personal } \\
\text { styles; }\end{array}$ & $\begin{array}{l}\text { Poetry writing } \\
\text { techniques }\end{array}$ & 15 & $\begin{array}{l}\text { "...started from imitating traditional Chinese poetry when he was in the 3rd } \\
\text { grade in elementary school. His major imitation focused on rhythm, format, } \\
\text { and the borrowing of certain poetic expressions he learnt by heart" (William, } \\
\text { Analytic Memo, January } 6,2016 \text { ). }\end{array}$ \\
\hline 22 & Rhyming & $\begin{array}{l}\text { Including consonance, alliteration, } \\
\text { and assonance in poetry } \\
\text { composition; }\end{array}$ & Poetic features & 20 & $\begin{array}{l}\text { "It just felt safer for me just to stick to the rhyme" (Steve, interview } \\
\text { transcript, November 25, 2015). }\end{array}$ \\
\hline 23 & Contrasting & $\begin{array}{l}\text { Including contrastive languages at } \\
\text { lexical, phrasal, or textual levels to } \\
\text { reveal the inner logic of poets' } \\
\text { thinking patterns; }\end{array}$ & Poetic features & 21 & $\begin{array}{l}\text {...this pair of color contrast shows the author's different feelings upon } \\
\text { immersing himself into the nature (Piaet, Analytic Memo, February 12, } \\
\text { 2016). }\end{array}$ \\
\hline 24 & Intertextuality & $\begin{array}{l}\text { The concept of borrowing in various } \\
\text { modes from other sources to current } \\
\text { poetic practices; }\end{array}$ & Poetic features & 9 & $\begin{array}{l}\text { "For myself, I think I read a lot classic poetry. It is very natural for me to } \\
\text { include some essences into my own writings. I like the concept of borrowing } \\
\text { because we can see a continuum in feelings, concerns along the history } \\
\text { across time and space" (ZY, interview transcript, translated, December 18, } \\
\text { 2015). }\end{array}$ \\
\hline 25 & $\begin{array}{l}\text { Writing through } \\
\text { cross-cultural } \\
\text { observations/ } \\
\text { Writing } \\
\text { cross-cultural } \\
\text { experiences }\end{array}$ & $\begin{array}{l}\text { Cultural differences become popular } \\
\text { referential themes in participants } \\
\text { poetry writings; }\end{array}$ & Poetic features & 1 & $\begin{array}{l}\text { "... While in that autumn, the same year, in Chinese culture, it is a season of } \\
\text { embracing outcomes and I reflect what I get-just like multiple colors } \\
\text { refracted in the river, I achieve a lot: development in my lab experience, } \\
\text { establishment of new friendships, traveling, doing exercise and building up } \\
\text { body health, and practicing my English, and sacrifice some, like being far } \\
\text { away from home and really experiencing homesick and tons of times in } \\
\text { lab...but I understand that these elements, positive or frustrated, they } \\
\text { compose my life, so I say colorful” (Piaet, interview transcript, translated, } \\
\text { February 15, 2016). }\end{array}$ \\
\hline
\end{tabular}




\begin{tabular}{|c|c|c|c|c|c|}
\hline \multicolumn{2}{|c|}{ Code } & \multirow[b]{2}{*}{\begin{tabular}{|l|} 
Explanation \\
Current members in Flow Wind \\
Poetry Workshop are all males, \\
except for the researcher as the \\
participant observer.
\end{tabular}} & \multirow[b]{2}{*}{ Categorization } & \multirow[b]{2}{*}{\begin{tabular}{|l|} 
Frequency \\
3
\end{tabular}} & \multirow[b]{2}{*}{$\begin{array}{l}\text { Example } \\
\text { "They just showed their attitudes like, people who write poetry are } \\
\text { considered very sensitive, emotional, or depressed...or getting trapped within } \\
\text { some relationship or love affairs-me as a male and as a science person, } \\
\text { shouldn't be like that..." (Conceptual Memo, Poetic Capital, February 16, } \\
\text { 2016). }\end{array}$} \\
\hline 26 & Male poets & & & & \\
\hline 27 & $\begin{array}{l}\text { Humanizing } \\
\text { literacy practice }\end{array}$ & $\begin{array}{l}\text { The current poetic practices move } \\
\text { beyond just participants' intellectual } \\
\text { abilities and reaches to the } \\
\text { comprehensive representation of } \\
\text { their whole human being (Hanauer, } \\
\text { 2010); }\end{array}$ & $\begin{array}{l}\text { Humanizing } \\
\text { research (Paris \& } \\
\text { Winn, 2013) }\end{array}$ & 8 & $\begin{array}{l}\text { "... and embedded in stories of people in other skin colors, the essence of } \\
\text { studying them remains the same: to cultivate people's empathy. And in order } \\
\text { to appreciate the beauty, sensitivity, wholeness, and details in classical } \\
\text { poetry, people are nourished to have both the physical and spiritual capacity } \\
\text { to love, to respect, and to understand the choices and tensions that poets } \\
\text { carefully depicted." (Conceptual Memo, Poetic Capital, February 16, 2016). }\end{array}$ \\
\hline 28 & $\begin{array}{l}\text { Holistic poetic } \\
\text { activities }\end{array}$ & $\begin{array}{l}\text { The current poetic practice places the } \\
\text { idea of encouraging living, thinking, } \\
\text { experiencing, and feeling person at } \\
\text { the center and participants are valued } \\
\text { as whole human being; }\end{array}$ & $\begin{array}{l}\text { Humanizing } \\
\text { research (Paris \& } \\
\text { Winn, 2013) }\end{array}$ & 10 & See Flow Wind Poetry Workshop Organization. \\
\hline 29 & $\begin{array}{l}\text { Collaborative } \\
\text { partnership } \\
\text { between } \\
\text { researcher and } \\
\text { participants }\end{array}$ & $\begin{array}{l}\text { The researcher has new } \\
\text { understandings towards participants' } \\
\text { beliefs through diving into their } \\
\text { poetry reading and writing } \\
\text { community, learning about their } \\
\text { interactive languages and cultural } \\
\text { references; }\end{array}$ & \begin{tabular}{|l} 
\\
Humanizing \\
research (Paris \& \\
Winn, 2013) \\
\end{tabular} & 5 & $\begin{array}{l}\text { “...my shared identities with all workshop members provided me with } \\
\text { valuable insider views towards participants' poetry writing and sharing } \\
\text { processes, their voices, identities, thoughts, cultural-related rhetoric, walking } \\
\text { me through the intersection of emic and etic perspectives." (Analytic Memo, } \\
\text { overview of research, March 20, 2016). }\end{array}$ \\
\hline 30 & $\begin{array}{l}\text { Participant } \\
\text { observer }\end{array}$ & $\begin{array}{l}\text { The researcher positions herself as } \\
\text { the insider of the current poetry } \\
\text { community, writing and sharing } \\
\text { original poems in both her L1 and L } 2 \\
\text { with all participants; meanwhile, the } \\
\text { researcher collects and analyzes data } \\
\text { for research purposes. }\end{array}$ & \begin{tabular}{|l} 
Humanizing \\
research (Paris \& \\
Winn, 2013) \\
\end{tabular} & 4 & $\begin{array}{l}\text { "As the participant observer, I wrote, read, and discussed original poems in } \\
\text { both L1 and L2 with the whole group, obtaining valuable feedback from } \\
\text { members and I found my linguistic, communicative, and social competencies } \\
\text { as a graduate students improved a lot" (Analytic Memo, overview of } \\
\text { research, March 20,2016). }\end{array}$ \\
\hline
\end{tabular}

